うな同報性が必要な会議に用いられるものであ り，1 カ所から送信された映像を衛星を通じて全 対地へ分配するとともに, 送信対地をリクエスト で適宜切換えて使用する. 衛星を利用しているこ とから, 他の方式に比べ多くの対地への適用が可 能である.NTTでも経済性から, 衛星を利用し た同報分配型のシステムを開発している。このシ ステムの構成を図 10 に示す.

\section{5. むす び}

テレビ会議は, 会議のための出張の代替手段とし て, 会議の効率化, 経済化をもたらすことが認めら れ, 各種の通信会議システムが用途に応じて, 各企業 で導入されつつある。そのなかで, 映像符号化装置は 符号処理技術の進展により，1.5 Mb/s から 384,64 $\mathrm{kb} / \mathrm{s}$ と低速化が図られ, 伝送コストの低減が進んで いる. また, 同一企業内の通信から他社さらに外国を 含めたいろいろな相手との接続も求められており, 異 なった装置あるいは異企業間でのテレビ会議や, 国際 間でのテレビ会議のためのシステム, あるいは符号化 装置の標準化も進められている。
ここでは, テレビ会議システムの現状および技術に ついて述べたが, テレビ会議は今後, 光ファイバや衛 星通信などの通信技術の進歩やディジタル画像処理, 半導体などの技術の進歩により, よりいっそうの経済 化・高機能化が図られ，ビジネス社会に不可欠なメデ イアとして発展していくものと期待される.

(昭和 63 年 6 月 28 日受付)

\section{〔参考文 献〕}

1) M. Yoshikawa,: "NTT's Improved Video Conferencing System" JTR, 29, July, pp. 25-31 (1987)

2）清水：“遠隔テレビ講義”, テレビ誌，42，5，pp.426429 (1988)

3）村田：“INS ネットサービスの概要”，NTT 施設， 40, 5. pp. 4-8 (1988)

4）吉川：“テレビ会議システムの技術”,ビジネスコミュニケ ーション, 23, 6, pp. 31-38 (1986)

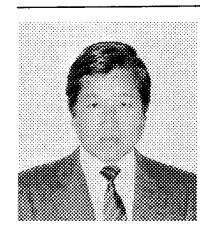

䏻川架光驾昭和 45 年, 東京工業大学工 学部電子工学科卒業. 同年, NTT 亿入社. 技術局画像通信部門, 横須賀通研有線伝送研 究室, 技術開発部高速広帯域部門等を経て, 現在, NTT 画像電信事業部サービス開発 部. 画像応答システム, テレビ会議システム 等の画像通信システムの開発に従事.

\title{
3-2 テレビ会議用符号化装置
}

正会員 古 閑 敏 夫 $^{\dagger}$

\section{1. ま え がき}

テレビ会議システムでは多数の端末機器が使用され るが, その中心のひとつに, テレビ会議画像(動画)を ディジタル的に圧縮し伝送する符号化装置（コーデッ ク）がある。通常は符号化装置といえば冗長度低減方 式が注目されるが, 実用化装置の場合には, むしろそ れ以外の機能が重視されることが多い.この観点に立

\section{2. 装置 構 成}

基本的には図 1 の構成により, 入出力信号として動 画像 (通常はカラー), 音声, 補助的情報であるディジ タルデータが用いられる.特に画像に対しては, 色信 号処理を中心とする前処理, 情報の圧縮を実行する冗 長度低減と可変長符号化が適用される. 受信側は送信 側と対称な構成で逆の処理を行う.
って本文では, $384 \mathrm{~kb} / \mathrm{s} \sim 1.5 \mathrm{Mb} / \mathrm{s}$ (1次 群）で1チャンネルのテレビ会議画像を伝 送する装置として, 筆者もその開発に参加 した NETEC-XV'を例にとり，それをで きるだけ一般化し, 必要な代表的機能を紹 介する。

\section{$\dagger$ 日本電気株式会社}

"3-2 Codec (Coder/Decoder) for Video Teleconfer encing" by Toshio Koga (Transmission Division, NEC Corporation, Tokyo)

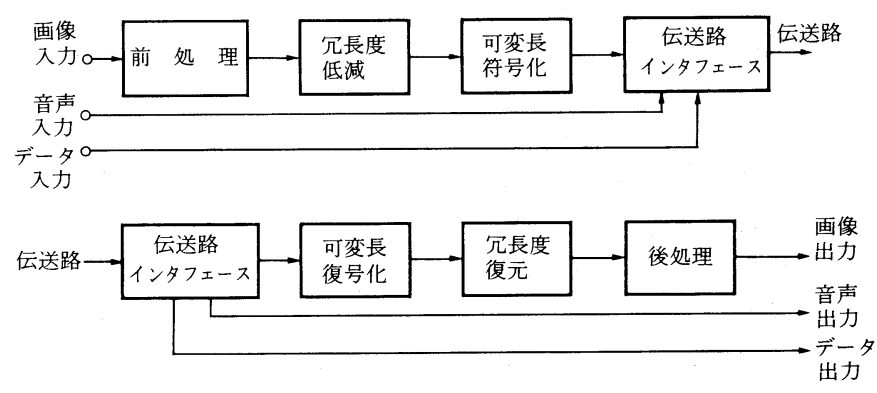

図 1 テレビ会議用画像符号化装置の基本構成 


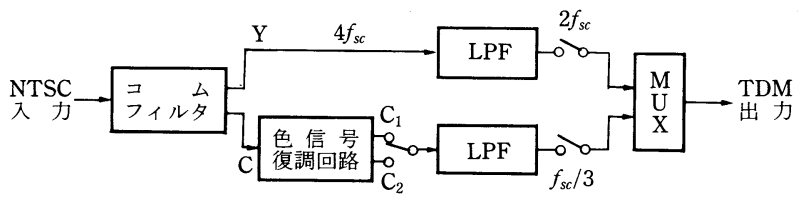

(a) NTSC/TDM 変換

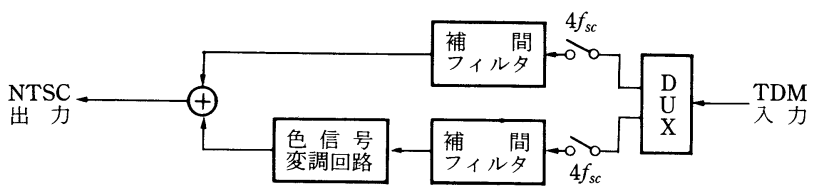

(b) TDM/NTSC 変換

図 2 カラーテレビ信号形式変換

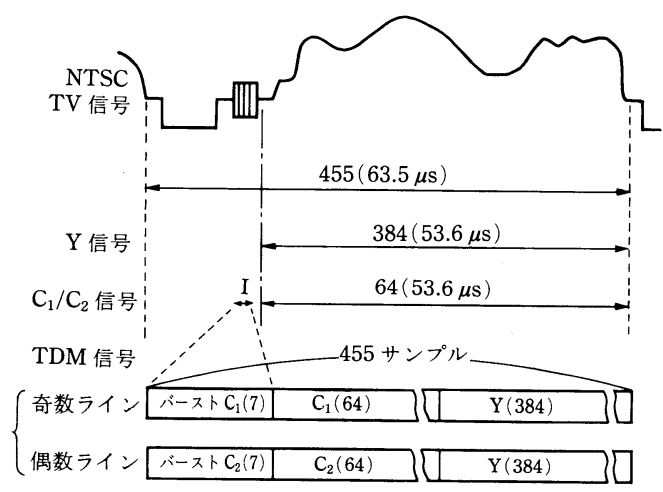

図 3 NTSC 信号と TDM 信号の関係

\section{1 前/後処理}

入力画像としてはNTSC などの複合信号が普通で あるので, 情報圧縮効果を高めるために輝度と色信号 の分離を行い, 画像形式を変換する.図2(a)に, NTSC から TDM（時分割多重）信号への変換部, 同 （b）にその逆変換部の基本ブロック図を示す.

図 2(a)において, 入力 NTSC 信号は櫛型フィル 夕により輝度 $(\mathrm{Y})$ と色 $(\mathrm{C})$ に分離され, 色信号に ついては, 復調後 $\mathrm{C}_{1} / \mathrm{C}_{2}$ として低域汇波され再標本化 される.もともとサブキャリア周波数 $\left(f_{s c}\right)$ の 4 倍 (14.3 MHz) にて標本化された入力信号は, 輝度は $2 f_{s c}$ に, 色 $\left(\mathrm{C}_{1} / \mathrm{C}_{2}\right)$ は $1 / 6$ に間引かれ, $f_{s c} / 3$ で再標本 化され，TDM 信号形式に従って多重化される。逆変 換部では, 図 2 (a)の LPF と同じ特性（5タップ, 帯域 $=3 \mathrm{MHz}:-3 \mathrm{~dB})$ の補間フィルタを用いて, 間 引された輝度を再生する. 色信号については，（3+ 3+9）のタップからなる帯域 $0.55 \mathrm{MHz}$ の補間フィル 夕を用いる。

図 3 に NTSC 信号と TDM 信号の両形式の関係を 示す． 1ライン当たり 455 サンプルを，TDM 信号で

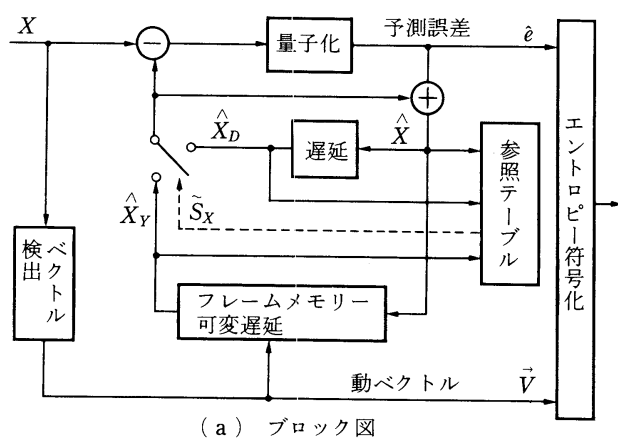

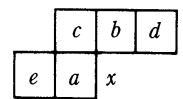

（））参照画素配置

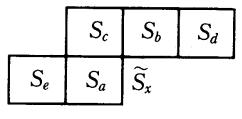

（c） 参照テーブル
図 4 動き補償フレーム間・フレーム内適応予測

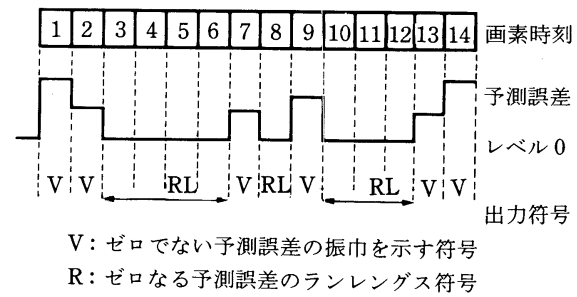

図 5 予測誤差の符号変換

はバースト情報に $7, \mathrm{C}_{1} / \mathrm{C}_{2}$ に $64, \mathrm{Y} に 384$ 画素割当 てている， $\mathrm{C}_{1}$ と $\mathrm{C}_{2}$ は線順次に多重化される。バース 卜情報は, 1 点の值を 7 回繰返して後段での処理の影 響を除去している。

\section{2 几長度低減}

この目的にて使用されるアルゴリズムは, 符号化装 置の種類と同じ数だけ存在するといっても過言ではな いが，ここでは，昨今広く使用されるようになってき た動き補償フレーム間予測とフレーム内予測(前值)を 画素単位で適応的に切替える適応予測を用いるものと する．実際の画像については，シーンチェンジや非常 に動きが速くて動き補償の効果が低下する場合がある ので, 速さに影響されないフレーム内予測は不可欠で ある. 図 4 に示す適応予測において，今から予測され る注目画素 $x$ において用いるべき予測方式は， $a$ と $b$ の 2 画素点での予測方式の比較結果 $S_{a}$ と $S_{b}$ により 決定される. 動き補償フレーム間予測に対する $S$ の 值を 0 ，フレーム内予測に対する $S$ の值を 1 とする と, 注目画素 $X$ において適当と推定される予測方式 $\widetilde{S}_{x}$ は, $\widetilde{S}_{x}=S_{a} \cdot S_{b}$ にて与えられる。 ただし, 各 $S$ の 
表 1 可変長符号 (予測誤差)

(a) 振幅用符号 (一部)

\begin{tabular}{|c|c|c|c|}
\hline レベル番号 & 符号長 & 符 & 号 語 \\
\hline 1 & 2 & $1 \mathrm{~S}$ & \\
\hline 2 & 5 & $\begin{array}{llll}0 & 1 & 1 & 0\end{array}$ & S \\
\hline 3 & 7 & $\begin{array}{llll}0 & 1 & 0 & 1\end{array}$ & $11 \mathrm{~S}$ \\
\hline 4 & 7 & $\begin{array}{llll}0 & 1 & 0 & 1\end{array}$ & $10 \mathrm{~S}$ \\
\hline 5 & 8 & 0101 & $011 \mathrm{~S}$ \\
\hline 6 & 8 & $\begin{array}{llll}0 & 1 & 0 & 1\end{array}$ & $010 \mathrm{~S}$ \\
\hline 7 & 8 & $\begin{array}{llll}0 & 1 & 0 & 1\end{array}$ & $\begin{array}{llll}0 & 0 & 1 & \mathrm{~S}\end{array}$ \\
\hline 8 & 8 & $\begin{array}{llll}0 & 1 & 0 & 1\end{array}$ & $000 \mathrm{~S}$ \\
\hline 9 & 9 & 0100 & $1111 \mathrm{~S}$ \\
\hline 10 & 9 & 01100 & $1110 \mathrm{~S}$ \\
\hline
\end{tabular}

（b）ランレングス用符号（一部）

\begin{tabular}{|c|c|c|c|c|c|c|c|c|}
\hline ラン長 & 符号長 & \multicolumn{3}{|c|}{ 符 } & 号 & 言 & 語 & 備考 \\
\hline 1 & 4 & 0 & 1 & 1 & 1 & & & \\
\hline 2 & 5 & 0 & 0 & 0 & 0 & 1 & & \\
\hline 3 & 5 & 0 & 0 & 0 & 0 & 0 & & \\
\hline 4 & 6 & 0 & 0 & 1 & 0 & 1 & 0 & \\
\hline 5 & 6 & 0 & 0 & 1 & 0 & 0 & 1 & \\
\hline 6 & 6 & 0 & 0 & 1 & 0 & 0 & 0 & \\
\hline 7 & 7 & 0 & 0 & 1 & 0 & 1 & 11 & \\
\hline $8 \sim 11$ & 7 & 0 & 0 & 1 & 1 & 0 & $\mathrm{X} X$ & $\begin{array}{c}\mathrm{X}= \\
11-\mathrm{RL}\end{array}$ \\
\hline
\end{tabular}

值は各画素点における予測処理が終了後に，いずれの 予測方式が実際には有利であったかを判定し定められ る.

この原理による適応予測は, 各々を単独で用いる場 合よりも優れた符号化能率を実現している2).

\section{3 エントロピー符号化}

前段の圥長度低減部にていくら能率を向上させて も，動ベクトルや予測誤差のエントロピー符号化にお いて不適当なアルゴリズムを選択すると無意味とな る. 図 5 に，予測誤差に対するエントロピー符号化の 例を示す。ここでは, 1 ビット/画素以下の平均情報 量を想定しているので，周知のハフマン符号化に対し てゼロの連続する長さ(ラン長)を能率良く表現するフ アクシミリで用いられ，ランレングス符号化を適応的 に併用する2⿰氵

図 5 における画素時刻 1 14 亿発生するゼロでない 予測誤差 (量子化後)を $V^{t}(t=1 \sim 14)$, ラン長を $R L(l)$ (ただし $l$ はラン長) とすると,この 14 個の予測誤差 は,

$$
V^{1}, V^{2}, R L(4), V^{7}, R L(1), V^{9}, R L(3), V^{13}, V^{14}
$$

で表される.ここで, 可変長符号としては $V$ 符号に ついて表 $1(\mathrm{a}) の ， R L$ 符号については表 1 (b)の該 当する符号語が用いられる。

動べクトルについても，同様の考え方が適用できる
ので説明は省略する．

このように，エントロピー符号化により得られる情 報量は瞬時的には不規則に発生しているので, 伝送路 における一定速度と整合をとるためにバッファメモリ 一にいったん格納される. 受信側にても, 復号化速度 と整合をとるために用いられる。

\section{4 伝送符号化}

エントロピー符号化により得られる圧縮された画像 信号そして音声, デー夕は, 一定の手順に従って伝送 路に送出される，その例を図 6 に示す，圧縮された画 像は, テレビ会議のように第三者へ会議内容が漏洩す るのを防止するための暗号化を行う．暗号化アルゴリ ズムとしては，米国商務省標準局 (NBS) による DES （Data Encryption Standard）が代表的である.

また，実際の伝送路ではビット誤りが不可避的であ るため, フレーム間予測を用いる装置では誤り訂正が 必要である。また, 回線詋りもビット誤りに限らず, バースト詰りが予想される場合には, ビットの並び替 えを行うインタリーバを使用する。例えば， 2 重誤り 訂正 $\mathrm{BCH}$ 符号に 16 相インタリーバを組合せると, $2 \times 16=32$ ビットまでのバースト誤りを訂正できる．

実用化装置では, 討正できない誤りが発生する場合 も想定しなければならず, その最も効果的な対策とし て，フレーム内相関のみを用いた圧縮を周期的に行う 周期的リフレッシュにより誤りのない画面を発生させ る. 類似の手法として, 送・受信部間でフレームメモ リーのパリティチェックを行い, 不一致の場合に全画 面を一気に書き替えるデマンドリフレッシュも併用さ れる。

音声信号は，ADPCM などにより $64 \mathrm{~kb} / \mathrm{s}$ に符号 化され, 画像信号の遅延に合わせるための遅延回路を 通る. 人間工学的には, 音声信号が画像信号よりも早 く呈示されると, 逆の場合と比較するとより不自然な 感じを与えるため, この音声に遅延を与えることは重 要である.ディジタルデータは $2400,4800 \mathrm{~b} / \mathrm{s}$ など の低速デー夕, $64 \mathrm{~kb} / \mathrm{s}$ 程度の高速デー夕などがあ る.これらの情報を多重化した段階では，0 と 1 の比

特 集ロテレビ電話・テレコンファレンス 
率は不定で, 回線系での再生中継に支障が生ずる可能 性があるため，スクランブラを用いて 0 と 1 のランダ ム化を図っている.

\section{5 付加機能}

実用化装置として，使い勝手の良さを向上させるこ とは非常に重要なことである.この例として，1チャ ンネルの動画像の代りに，(1)スプリットスクリーンや (2)フィールド多重, などにより 2 チャンネルの動画像 を伝送する多重伝送機能, 会議中に用いる諸種の静止 画像 (グラフィックス) 伝送機能, 2 画面同時表示や 1 画面内に動画とグラフィックスを混合表示する機能, 表置内外の障害発生時に切分けのためのループバック 機能（例えば，アナログ， A/D-D/A，TDM 変換-逆 変換, 予測符号化-復号化, 送受のバッファメモリー での折返し), 入力画像の断やレベル異常, 回線障害 による伝送フレーム同期検出不能, 等のアラーム機能 などの付加機能がある. 装置全体の中に占めるハード ウェアあるいはソフトウェアの比重は, むしろ付加機 能の方が動画像の圧縮部分よりも大きい。また音声に 関しては，エコーを阻止・抑圧するためのエコーキャ ンセラを用いることができる.

その他の付加機能の例としては, 伝送速度の選択, 上記付加機能の選択あるいは使用の可否の集中制御お よび表示，さらにはリモート制御など多様である.

\section{3. 今後の符号化装置}

実際に使用されている符号化装置の種類, 数が少な いうちは問題とはならなかったが, 徐々に普及してい くにつれ，相互に接続できない問題が顕在化してき た。これに対して, CCITTにて符号化アルゴリズム の国際標準化が前会期（1981〜 1984）から始められ， PCM 1 次群対応としては大略決着がついた。 その 後, 1 次群以下 (サブレート)である $n \times 384 \mathrm{~kb} / \mathrm{s}(n=$ 1〜6)を対象とした符号化アルゴリズムが主として検 討され，その大筋は H. 261 にまとめられる.

基本方式としては, 動き補償フレーム間予測誤差に 直交変換を適用するもので, 直交変換としては DCT が用いられることになっており，装置の試作も行われ た ${ }^{4) 5)}$. 最新の情報によれば, この $n \times 384 \mathrm{~kb} / \mathrm{s}$ での 符号化アルゴリズム (H. 261) を $64 \mathrm{~kb} / \mathrm{s}$ にまで拡張す る方向で, さらに検討が続けられている.

ひとたび標準アルゴリズムが制定されると, 符号化 装置を供給する側からは, それぞれの特色を出すため に, 上記の付加機能のさらなる充実, 装置の低価格 化, 小型化, 低電力化, 独自の符号化アルゴリズムの 搭載などを狙って, 各種処理部回路の LSI 化や汎用
あるいは信号処理用プロセッサを用いる CPU 化の方 向が明確化すると思われる。

従来, 布線論理によるところが大であった画像の符 号化装置にも, ソフトウェア化の波は着実に寄せてき ている.ここでも VLSI 技術の進展が大きく期待され る.

\section{4. む す び}

テレビ会議画像の符号化装置としては, 分類方法に もよるが約 5〜6 社程度が提供しており，すべてを紹 介することは困難であること，および，本文の目的が 符号化装置のカタログ值の比較ではなく, むしろ実用 化装置として基本的に何が必要であるかを説明するこ とにあるため，一符号化装置を例にとり，できるだけ 一般化し, かつ記述が発散しないようにつとめた.

現状は機種の数だけ符号化アルゴリズムがあるとい っても過言ではないが，やがて CCITTによる標準化 とともに装置ハードウェア構成も工夫改良がなされ， 複数のアルゴリズムが同一の装置にて実行可能となる と思われる.こうなると異機種間の相互接続も容易化 され，広範囲の人々と交信でき通信の質および便利さ は大幅に増加しよう。

今後は, 符号化装置の質的向上と国内外の ISDN サービスの普及計画とが相互に作用を及ぼし，画像通 信サービスが, 従来とは明確に異なる早いペースで普 及すると思われる。これが現実的になりつつある状況 は，筆者を含め符号化装置の開発に関わる者にとり， この上なく勇気を与えるものである.

(昭和 63 年 8 月 11 日受付)

\section{〔参 考 文 献〕}

1) K. Inuma, et al.: "A Motion-compensated Inter-frame Codec", in Image Coding, M. Kunt, T. S. Huang, editors, Proc. SPIE 594, pp. 194-201 (1986)

2）古閑ほか：“動き補償フレーム間フコレーム内予測とエント ロピー符号化”、テレビ誌，39，10 (1985)

3) S. Okubo, et al.: "Progress of CCITT Standardization on $\mathrm{n} \times 384 \mathrm{~kb} / \mathrm{s}$ Video Codec", Proc. IEEE GLOBECOM' 87 , vol. 2.1.1-2.1.4 (Tokyo) (1987)

4）羽鳥ほか：“テレビ会議用 $384 \mathrm{kbit} / \mathrm{s}$ 伝送高能率符号化装 置”, 国際通信の研究, No. 136, pp. 87-94 (1988)

5) N. Mukawa, et al.: " $384 \mathrm{kbit} / \mathrm{s}$ Video Codec", Review of the Electrical Commumications, Laboratories NTT, Japan, 36, 2, pp. 225-231 (1988)

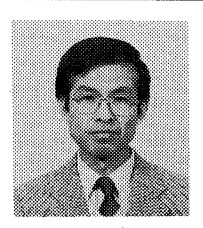

古閑 敏繁 昭和 46 年, 九州大学大学院 修士課程修了. 同年, 日本電気 (株) 亿入社. 中央研究所を経て, 現在, 同社伝送通信事業 部第二開発部に勤務. 画像信号のディジタル 処理, 特にテレビ信号の带域圧縮方式および 画像通信に関する装置・システムの開発化従 事. 正会員. 